\title{
A recombinant bovine herpesvirus 5 defective in thymidine kinase and glycoprotein $E$ is attenuated and immunogenic for calves ${ }^{1}$
}

\author{
Deniz Anziliero², Cyndia M. B. dos Santos², Fernando V. Bauermann², \\ Leila Cardozo ${ }^{3}$, Lucas M. Bernardes², Mário C. S. Brum ${ }^{4}$, Rudi Weiblen² \\ and Eduardo Furtado Flores ${ }^{2^{*}}$
}

\begin{abstract}
Anziliero D., Santos C.M.B., Bauermann F.V., Cardozo L., Bernardes L.M., Brum M.C.S., Weiblen R. \& Flores E.F. 2011. A recombinant bovine herpesvirus 5 defective in thymidine kinase and glycoprotein $E$ is attenuated and immunogenic for calves. Pesquisa Veterinária Brasileira 31(1):23-30. Departamento de Medicina Veterinária Preventiva, Universidade Federal de Santa Maria, Camobi, Santa Maria, RS 97105-900, Brazil. E-mail: eduardofurtadoflores@gmail.com

Bovine herpesvirus 5 (BoHV-5) is an important pathogen of cattle in South America and efforts have been made to produce safer and more effective vaccines. In addition to afford protection, herpesvirus vaccines should allow serological differentiation of vaccinated from naturally, latently infected animals. We previously reported the construction and characterization in vitro of a double mutant BoHV-5 (BoHV- $5 \mathrm{gE} / \mathrm{TK} \square \Delta$ ) lacking the genes encoding thymidine kinase (tk) for attenuation, and glycoprotein $\mathrm{E}(\mathrm{gE})$ as the antigenic marker, as a vaccine candidate strain (Brum et al. 2010a). The present article reports an investigation on the attenuation and immunogenicity of this recombinant in calves. In a first experiment, 80 to 90 -day-old seronegative calves $(n=6)$ inoculated intranasally with the recombinant (titer of $10^{7.5} \mathrm{TCID}_{50}$ ) shed virus in low to moderate titers in nasal secretions for up to 6 days, yet did not develop any respiratory, systemic or neurological signs of infection. At day 30 post-infection (pi) all calves had BoHV-5 specific neutralizing (VN) antibodies in titers of 4 to 8 and were negative for anti-gE antibodies in a commercial ELISA test. Administration of dexamethasone $(0.1 \mathrm{mg} / \mathrm{kg} /$ day during 5 days $)$ to four of these calves at day 42 pi did not result in virus shedding or increase in VN titers, indicating lack of viral reactivation. Secondly, a group of 8 -month-old calves $(n=9)$ vaccinated intramuscularly (IM) with the recombinant virus $\left(10^{7.5} \mathrm{TCID}_{50} /\right.$ animal) did not shed virus in nasal secretions, remained healthy and developed VN titers from 2 to 8 at day 42 post-vaccination (pv), remaining negative for gE antibodies. Lastly, 21 calves (around 10 months old) maintained under field conditions were vaccinated IM with the recombinant virus (titer of $10^{7.3} \mathrm{TCID}_{50}$ ). All vaccinated animals developed $\mathrm{VN}$ titers from 2 to 16 at day $30 \mathrm{pv}$. A boost vaccination performed at day $240 \mathrm{pv}$ resulted in a rapid and strong anamnestic antibody response, with VN titers reaching from 16 to 256 at day 14 post-booster. Again, serum samples remained negative for $\mathrm{gE}$ antibodies. Selected serum samples from vaccinated animals showed a broad VN activity against nine BoHV-5 and eight BoHV-1 field isolates. These results show that the recombinant virus is attenuated, immunogenic for calves and induces an antibody response differentiable
\end{abstract}

\footnotetext{
${ }^{1}$ Received on July 5, 2010.

Accepted for publication on August 23, 2010.

2 Setor de Virologia, Departamento de Medicina Veterinária Preventiva (DMVP), Centro de Ciências Rurais (CCR), Universidade Federal de Santa Maria (UFSM), Bairro Camobi, Santa Maria, RS 97105900, Brazil. *Corresponding author: eduardofurtadoflores@gmail.com
}

\footnotetext{
${ }^{3}$ Programa de Pós-Graduação em Medicina Veterinária (PPGMV), Centro de Ciências Rurais, Universidade Federal de Santa Maria, Avenida Roraima 1000, Cidade Universitária, Bairro Camobi, Santa Maria, RS.

${ }^{4}$ Faculdade de Veterinária, Universidade do Pampa (Unipampa), BR 472 Km 585, Uruguaiana, RS 97500-970, Brazil.
} 
from that induced by natural infection. Thus, the recombinant BoHV- $5 \mathrm{gE} / \mathrm{TK} \Delta$ is an adequate candidate strain for a modified live vaccine.

INDEX TERMS: Bovine herpesvirus 5, gene deletion, recombinant, differential vaccine, attenuation.

RESUMO.- [Cepa recombinante do herpesvírus bovino tipo 5 defectiva na timidina quinase e glicoproteína $E$ é atenuada e imunogênica para bezerros.] O herpesvírus bovino tipo 5 (BoHV-5) é um importante patógeno de bovinos na América do Sul e tem suscitado esforços para o desenvolvimento de vacinas mais seguras e eficazes. Além de conferirem proteção, vacinas contra os herpesvírus animais devem permitir a diferenciação sorológica entre animais vacinados e infectados naturalmente. Foi recentemente relatada a construção e caracterização in vitro de um recombinante do BoHV-5 defectivo na enzima timidina quinase (tk) para atenuação e, na glicoproteína $\mathrm{E}$ (gE) como marcador antigênico, como potencial cepa vacinal (Brum et al. 2010a). O presente artigo relata uma investigação sobre da atenuação e imunogenicidade do recombinante BoHV-5gE/TK $\Delta$ em bezerros. Em um primeiro experimento, bezerros soronegativos, com 80 a 90 dias de idade $(n=6)$, inoculados pela via intranasal (IN) com o vírus recombinante (título de $10^{7,5} \mathrm{TCID}_{50}$ ) excretaram baixos títulos de vírus nas secreções nasais por até seis dias, mas não desenvolveram sinais sistêmicos, respiratórios ou neurológicos. No dia 30 pós-infecção (pi), todos os animais possuíam anticorpos neutralizantes contra o BoHV-5, em títulos entre 4 e 8, mas permaneceram negativos para anticorpos contra a gE. Administração de dexametasona (Dx) a quatro desses bezerros no dia $42 \mathrm{pi}(0.1 \mathrm{mg} /$ $\mathrm{kg} /$ dia durante 5 dias) não resultou em excreção viral ou em aumento dos títulos de anticorpos, indicando ausência de reativação viral. Em um segundo experimento, vacinação intramuscular (IM) de bezerros com 8 meses de idade $(\mathrm{n}=9)$ com o recombinante $\left(10^{7,5} \mathrm{TCID}_{50} /\right.$ animal) não resultou em excreção viral ou em manifestações clínicas. Os animais vacinados desenvolveram anticorpos neutralizantes em títulos de 2 a 8 no dia 42 pós-vacinação (PV) e permaneceram negativos para anticorpos anti-gE. Finalmente, 21 bezerros (aproximadamente 10 meses de idade) mantidos a campo foram vacinados com o recombinante $\left(10^{7,3} \mathrm{TCID}_{50}\right)$ pela via IM. Todos os animais vacinados desenvolveram anticorpos neutralizantes em títulos de 2 a 16 no dia 30pv. Revacinação desses animais no dia 240 pv provocou uma resposta anamnéstica rápida e intensa, resultando em títulos neutralizantes entre 16 e 256 no dia 14 pós-revacinação. O soro de todos os animais permaneceu negativos para anticorpos contra a gE. Amostras de soro dos animais vacinados apresentaram atividade neutralizante cruzada frente a nove isolados de BoHV5 e oito de BoHV-1. Esses resultados demonstram que o recombinante é atenuado e imunogênico para bezerros e induz uma resposta sorológica diferenciável da resposta à infecção natural. Portanto, o recombinante se constitui em um potencial candidato a cepa vacinal.

TERMOS DE INDEXAÇÃO: Herpesvírus bovino 5, deleção gênica, recombinante, vacina diferencial, atenuação.

\section{INTRODUCTION}

Bovine herpesvirus type 5 (BoHV-5) is the agent of meningoencephalitis in cattle and is closely related to bovine herpesvirus 1 (BoHV-1), a virus associated with respiratory (infectious bovine rhinotracheitis, IBR), reproductive disease (vulvovaginitis/balanopostitis IPV/IBP) and abortions in cattle (Studdert 1990, Kahrs 2001). BoHV-1 and BoHV-5 are enveloped, double stranded DNA viruses, belonging to the subfamily Alphaherpesvirinae, genus Varicellovirus (Roizman 1992). Following primary infection, these viruses establish lifelong latency in neurons of the trigeminal ganglia (TG) or central nervous system (CNS) (Rock 1994, Vogel et al. 2003). Latently infected animals are the main reservoirs of infection in nature, from which the virus can be periodically reactivated and transmitted to susceptible animals (Rock 1994, Engels \& Ackermann 1996).

Bovine herperviruses 1 and 5 share a high antigenic similarity and display an extensive serological crossreactivity. As a consequence, these viruses cannot be distinguished by routine serological/immunodiagnostic tests (Bratanich et al. 1991, Vogel et al. 2002, Holtz et al. 2009). These agents are widespread among South American cattle and are associated with important losses to the livestock industry. BoHV-5 infection seems to be particularly prevalent in Argentina and Brazil where numerous outbreaks are reported every year (Carrillo et al. 1983, Salvador et al. 1998, Colodel et al. 2002, Rissi et al. 2007).

Vaccination represents an efficient strategy to control bovine herpesvirus infections in the field (Ackermann \& Engels 2006, Van Drunen-Littel van den Hurk 2006). The main goal of vaccination is to prevent or reduce the severity of clinical disease and reduce/prevent virus shedding and transmission (Ackermann \& Engels 2006, Van Drunen-Littel van den Hurk, 2006). Several BoHV-1 vaccines are commercially available in South America, most of them based on conventional inactivated viruses and, at least one, containing a temperature-sensitive, modified live virus (MLV) (Flores, E.F. unpublished). Few vaccines contain BoHV-5 antigens in their formulations, none of them based on live virus. Nonetheless, the antigenic similarity and serological cross-reactivity between BoHV-1 and -5 have led to the concept that vaccines containing either virus could be of value to control infection by the homologous and also by the heterologous virus (Bratanich et al. 1991, Vogel et al. 2002, Del Medico Zajac et al. 2006, Brum et al. 2010b). In any case, an important restriction for the use of conventional vaccines - either inactivated or live - is the impossibility of differentiating between vaccinated and naturally, latently infected animals (Van Oirschot et al. 1996). This restriction assumes special importance considering scenarios of control/ eradication programs either at herd or at country level (Van Oirschot et al. 1996, Ackermann \& Engels 2006, Van DrunenLittel van den Hurk 2006). 
Differential vaccines (DIVA, for "differentiating infected from vaccinated animals"), usually produced by gene deletion, are based on the capacity of the vaccine virus to induce a serological response differentiable from that induced by natural infection (Van Oirschot et al. 1996). Such vaccines have been widely used to control pseudorabies virus (PRV) and BoHV-1 infections in several countries (Van Oirschot et al. 1996, Van Drunen-Littel van den Hurk 2006). A gE-deleted BoHV-1 recombinant strain has been previously constructed out a Brazilian BoHV-1.2 isolate (Franco et al. 2002a), but is not yet commercially available.

The non-essential viral envelope glycoprotein $\mathrm{E}(\mathrm{gE})$ is considered the most suitable antigenic marker for the production of BoHV-1 differential vaccines (Van Oirschot et al. 1996, Kaashoek et al. 1996, 1998). In addition to provide an antigenic marker, gE deletion from BoHV-1 and BoHV-5 genomes contributes for virus attenuation (Van Engelenburg et al. 1994, Kaashoek et al. 1996, 1998, Franco et al. 2002b, Silva et al. 2010). Nevertheless, the sole deletion of $\mathrm{gE}$ from BoHV-5 genome does not result in complete attenuation, and additional gene (s) deletion (s) may be required to produce fully attenuated vaccine strains (Chowdhury et al. 2000, Silva et al. 2010). In this sense, the deletion of thymidine kinase (tk) gene has shown to significantly contribute for attenuation of BoHV-1 vaccine candidate strains (Kit et al. 1985, Van Engelenburg et al. 1994, Kaashoek et al. 1996). Recently, a tk-deleted recombinant BoHV-5 was shown to be fully attenuated in a rabbit model (Silva et al. 2010).

Our group described the construction and in vitro characterization of a double mutant BoHV-5 lacking both $\mathrm{gE}$ and tk genes (BoHV-5gE $\Delta$ TK $\Delta$ ) out of a highly neurovirulent Brazilian BoHV-5 strain (Brum et al. 2010a). The experiments described in the present article investigated: I. The virulence/ attenuation of the recombinant strain in calves following intranasal (IN) and intramuscular (IM) inoculation; II. The ability of the recombinant to reactivate latent infection and, III. Its immunogenicity in calves following primary and booster immunizations. IV. In addition, the spectrum of serological reactivity of BoHV- $5 \mathrm{gE} \Delta \mathrm{TK} \Delta$ was assayed by testing sera from immunized calves against several BoHV-1 and BoHV5 field isolates.

\section{Experimental design}

Three independent experiments were conducted to investigate the virulence/attenuation and immunogenicity of the recombinant strain BoHV-5 gE/TK $\Delta$ for calves. In the first experiment (Exp.1), six calves were inoculated intranasally (IN) and the acute infection was monitored in virological, clinical and serological aspects. At day $42 \mathrm{pi}$, an attempt to reactivate latent infection was performed by treating the calves with dexamethasone (Dx). The second experiment (Exp.2) consisted of intramuscular (IM) vaccination of nine calves with the recombinant virus, followed by virological, clinical and serological monitoring. In the third experiment (Exp.3), 21 calves were vaccinated IM and revaccinated 240 days later; serology was performed after vaccination and after booster. Post-inoculation/ vaccination sera from all groups were tested by virus neutralizing (VN) assays and selected samples were also assayed for gE antibodies.

\section{Cells and viruses}

All procedures of virus amplification, quantitation, isolation and VN assays used a MDBK-derived cell line named CRIB (Flores \& Donis 1995). Cells were cultured in minimal essential medium (MEM), containing ampicillin $(1.6 \mathrm{mg} / \mathrm{L})$, streptomycin $(0.4 \mathrm{mg} / \mathrm{L})$, amphotericin $(2 \mathrm{mg} / \mathrm{L})$, supplemented with $10 \%$ fetal bovine serum (Cultilab, Brazil). The construction and characterization in vitro of the double mutant BoHV-5 gE/TK $\Delta$ have been previously described (Brum et al. 2010a). The viruses used for cross-VN assays were the parental BoHV-5 strain (SV-507/99), nine BoHV-5 and eight BoHV-1 Brazilian isolates previously characterized by Silva et al. (2007). Virus stocks of all viruses were produced in CRIB cells, aliquoted and stored at $-80^{\circ} \mathrm{C}$.

\section{Animals, virus inoculation and monitoring}

Experiment 1. Six Holstein male calves, aging 80-90 days, seronegative to BoHV-1 and BoHV- 5 by VN were used for virus inoculation. The animals were inoculated by IN instillation of a virus suspension containing $10^{7.5} \mathrm{TCID}_{50}$ of the recombinant virus (passage 5). During 20 days, the animals were monitored clinically: Body temperature, nasal and respiratory signs, systemic and/or neurological signs. Nasal swabs collected on a daily basis were submitted to virus isolation. Blood for serology was collected at day 0 and $32 \mathrm{pi}$. At day $42 \mathrm{pi}$, the calves were submitted to Dx administration (Decadronal, etc) in a regimen of five daily dosis of $0.1 \mathrm{mg} / \mathrm{kg} /$ day by the IM route. After Dx treatment, the animals were monitored daily up to day $15 \mathrm{pDx}$ as described during acute infection. Nasal swabs were collected for virus isolation and quantitation; serum samples were collected for serology.

Experiment 2. nine calves approximately 8 months-old, of both genders, weighing around $160 \mathrm{~kg}$ and tested negative for BoHV-1 and BoHV-5 antibodies were used. The animals were inoculated IM with a virus suspension containing $10^{7.5} \mathrm{TCID}_{50}$ of the recombinant virus. Clinical examination and collection of nasal secretions for virus isolation were performed in a daily basis up to day $15 \mathrm{pi}$. Blood for serology was collected at day 0 , 14, 21 and 42 pi.

Experiment 3. 24 calves of both genders, approximately 10 months-old, weighing around $120-140 \mathrm{~kg}$ and tested negative for BoHV-1 and BoHV-5 antibodies were vaccinated IM with a virus suspension containing the recombinant virus $\left(10^{7.3} \mathrm{TCID}_{50}\right)$ and revaccinated (IM, same viral dose) at day 240 post vaccination (pv). Blood for serology was collected at days 30 , 70 and 240 pv and day 14 post-booster (254 days pv).

\section{Sample processing}

Virus isolation and quantitation. Nasal swabs collected from inoculated animals were submitted to virus isolation. The swabs were vortexed vigorously, low-speed centrifuged. The supernatants were inoculated onto CRIB cells monolayers grown on 24-well plates and submitted to three passages of five days each. The infectivity of the samples that were positive for virus was subsequently quantified by limiting dilution. Virus titers were calculated according to Reed \& Muench (1938) and expressed as $\log _{10} \mathrm{TCID}_{50} / \mathrm{mL}$.

Serology. Serum samples were submitted to a standard $\mathrm{VN}$ assay, testing two-fold dilutions of sera against a fixed dose 
$\left(100-200\right.$ TCID $\left._{50}\right)$ of the recombinant virus. Serum samples collected from selected animals in Experiment \# 3 were tested by $\mathrm{VN}$ against nine BoHV-5 and eight BoHV-1 isolates (Fig.1). The virus-sera mixtures were incubated $2 \mathrm{~h}$, following by addition of a suspension of CRIB cells; test readings were conducted after $72 \mathrm{~h}$ of incubation. The antibody titers, expressed as the reciprocal of the highest dilution of sera that prevented the production of cytopathic effect (cpe) in the monolayers, were transformed in GMT (geometric mean titer [Thrusfield 1986]) for the calculation of the mean antibody titers of each group. Selected serum samples of animals from all groups were also submitted to a gE-specific ELISA (IDEXX Inc.).

All procedures of animal handling and experimentation were conducted under veterinary supervision and according to recommendations by the Brazilian Committee of Animal Experimentation (COBEA, law $\# 6.638$ of May, $8^{\text {th }}, 1979$ ). The experiment was approved by an Institutional Animal Ethics Committee (UFSM, approval \# 48/2006).

\section{RESULTS}

Intranasal inoculation of BoHV-5gE/TK $\Delta$ in young calves (Experiment 1).

Even though an eventual live vaccine using the recombinant strain would be designed for parenteral administration, we initially investigated its virulence/attenuation for calves upon IN instillation. Inoculation of a virus suspension containing the recombinant virus (titer of $10^{7.3} \mathrm{TCID}_{50}$ ) in the nose of young calves was followed by virus replication and shedding from day 1 to 6 pi (Table 1). Virus shedding titers peaked at $10^{4.8} \mathrm{TCID}_{50} / \mathrm{ml}$ at day $4 \mathrm{pi}$ and then progressively declined (not shown). No infectivity was detected in swabs collected after day 6pi. Inoculated animals did not present any systemic or neurological sign of infection; only a mild nasal secretion was observed in two calves between days 2 and $4 \mathrm{pi}$. All inoculated animals seroconverted to BoHV-5 after acute infection. VN titers to the homologous virus ranged from 4 to 8 at day 32 pi. Despite of being VN positive, at day 32pi all calves remained negative for $\mathrm{gE}$ antibodies (Table 1 ).

Attempts to reactivate latent infection at day 42pi in four animals through $\mathrm{Dx}$ administration failed to induce virus shedding or increase in VN titers (Table 1). Likewise, Dxtreated calves did not develop local or systemic signs of infection after treatment. Again, calves inoculated with the recombinant and treated with $\mathrm{Dx}$ remained negative for $\mathrm{gE}$ antibodies at day $30 \mathrm{pDx}$.

These results demonstrate that the recombinant virus is attenuated for 3-months-old calves upon IN instillation even in a considerably high titer - yet replicates in the nose as to induce a measurable VN response. Further, the failure to recover virus and to detect increase in VN titers after Dx treatment indicates that the recombinant virus is not readily reactivated from latency. Lastly, inoculated calves did not produce anti-gE antibodies.

Taken together, these results demonstrate the attenuation and immunogenicity of the recombinant virus for 3 months-old calves. Previously, we have demonstrated the attenuation of BoHV- $5 \mathrm{gE} / \mathrm{TK} \Delta$ strain for rabbits, an experimental model for BoHV-5 neurological disease (Silva et al., 2010).

\section{Intramuscular vaccination of 8-months-old calves with BoHV-5gE/TK"' (Experiment 2)}

Next, we inoculated calves with the recombinant virus by the IM route to investigate its ability to replicate and to induce a VN response upon parenteral administration. None of the calves inoculated IM with the vaccine candidate strain (titer of $10^{7.5} \mathrm{TCID}_{50}$ ) shed virus in nasal secretions or presented systemic signs of infection in the days following inoculation (Table 2; not shown). VN tests performed with sera collected at day 14,21 and $42 \mathrm{pv}$ revealed neutralizing titers from 2 to 4 to the homologous virus. All calves were negative for $\mathrm{gE}$ antibodies in the anti-gE-specific ELISA performed at day $42 \mathrm{pv}$ (Table 2).

\section{Intramuscular vaccination of 10-months-old calves with BoHV-5gE/TK $\Delta$ (Experiment 3)}

The last experiment was designed to evaluate the VN serological response to vaccination in 24 calves after IM vaccination and following a boost immunization performed 8 months later. Primary immunization resulted in detectable VN titers in 15/21 animals, in titers ranging from 2 to 8 at day $30 \mathrm{pv}$ (Table 3 ). The vaccinated calves were maintained further, and VN tests performed with sera collected at day 240 pv revealed a slight reduction in mean titers.(Table 3, Fig.1). A boost immunization performed at day 240 pv resulted in a strong anamnestic response in all animals, with

Table 1. Virological and serological findings after intranasal inoculation of $\mathbf{8 0}$ to 90 -days old calves with the recombinant virus BoHV-5gE/TK" (Exp.1)

\begin{tabular}{|c|c|c|c|c|c|c|c|}
\hline \multirow{2}{*}{$\begin{array}{c}\text { Animal } \\
\#\end{array}$} & \multicolumn{3}{|c|}{ Acute infection } & \multirow{2}{*}{$\begin{array}{l}\text { VN antibodies } \\
\text { (day } 42 \text { pi) }\end{array}$} & \multicolumn{3}{|c|}{ Post Dx administration $(\mathrm{pDx})^{\mathrm{b}}$} \\
\hline & $\begin{array}{l}\text { Virus shedding } \\
\text { (days) }\end{array}$ & $\begin{array}{l}\text { VN antibodies } \\
\text { (day 32pi) }^{\mathrm{a}}\end{array}$ & $\begin{array}{l}\text { ELISA gE } \\
\text { (day 32pi) }\end{array}$ & & $\begin{array}{c}\text { Virus } \\
\text { shedding }\end{array}$ & $\begin{array}{l}\text { VN antibodies } \\
\text { (day 30pDX) }\end{array}$ & $\begin{array}{c}\text { ELISA gE } \\
\text { (day 30pDx) }\end{array}$ \\
\hline 44 & $1-6$ & 8 & $-c$ & 4 & $-d$ & 4 & $-c$ \\
\hline 45 & $1-6$ & 8 & - & 8 & - & 8 & - \\
\hline 3276 & $1-6$ & 4 & - & 8 & $\mathrm{nt}^{\mathrm{e}}$ & NT & $\mathrm{nt}$ \\
\hline 3278 & $1-6$ & 4 & - & 4 & nt & NT & $\mathrm{nt}$ \\
\hline 3280 & $1-6$ & 4 & - & 4 & - & 4 & - \\
\hline 4324 & $1-6$ & 8 & - & 8 & - & 4 & - \\
\hline
\end{tabular}

a All animals were seronegative at the day of virus inoculation (VN titers $<2$ ); ${ }^{b}$ Dexamethasone treatment started at day 42 pi (see Material \& Methods); ${ }^{c}$ Negative in the anti-gE ELISA; d Nasal swabs were. negative for virus up to day 20 pi and up to day $15 \mathrm{pDx}$; ${ }^{\text {e }}$ Calves 3276 and 3278 were not submitted to Dx administration. 
Table 2. Virological and serological findings after intramuscular inoculation of 8-months-old calves with the recombinant virus BoHV-5gE/TK" (Exp.2)

\begin{tabular}{|c|c|c|c|c|c|c|}
\hline \multirow[t]{2}{*}{ Animal } & \multirow{2}{*}{$\begin{array}{c}\text { Virus } \\
\text { shedding }\end{array}$} & \multirow{2}{*}{$\begin{array}{l}\text { Clinical } \\
\text { signs }\end{array}$} & \multicolumn{3}{|c|}{ Virus neutralizing titers } & \multirow{2}{*}{$\begin{array}{l}{ }^{\mathrm{C}} \text { ELISA gE } \\
\text { day } 42 \mathrm{pi}\end{array}$} \\
\hline & & & day $14 p$ & day $21 \mathrm{pi}$ & day 42 pi & \\
\hline 162 & $-a$ & $n / a^{b}$ & 4 & 4 & 4 & $-d$ \\
\hline 193 & - & $\mathrm{n} / \mathrm{a}$ & 4 & 4 & 2 & - \\
\hline 188 & - & $\mathrm{n} / \mathrm{a}$ & 2 & 4 & 2 & - \\
\hline 101 & - & $\mathrm{n} / \mathrm{a}$ & 2 & 4 & 2 & - \\
\hline 194 & - & $\mathrm{n} / \mathrm{a}$ & 2 & 2 & 2 & - \\
\hline 191 & - & $\mathrm{n} / \mathrm{a}$ & 4 & 4 & 4 & - \\
\hline 130 & - & $\mathrm{n} / \mathrm{a}$ & 2 & 4 & 2 & - \\
\hline 164 & - & $\mathrm{n} / \mathrm{a}$ & 4 & 2 & 2 & - \\
\hline 192 & - & $\mathrm{n} / \mathrm{a}$ & 4 & 2 & 2 & - \\
\hline
\end{tabular}

a Nasal swabs were negative for virus up to day $15 \mathrm{pi}$; ${ }^{\mathrm{b}}$ No clinical signs were observed during monitoring; ${ }^{\mathrm{C}}$ All animals were seronegative at the day of virus administration (VN titers <2); ${ }^{d}$ Negative in the anti-gE ELISA.

Table 3. Serological response developed by calves vaccinated intramuscularly with the recombinant virus BoHV-5gE/TK" (Exp.3)

\begin{tabular}{|c|c|c|}
\hline \multirow[b]{2}{*}{ Animal } & \multicolumn{2}{|c|}{ Virus neutralizing titers ${ }^{a}$} \\
\hline & $\begin{array}{c}\text { Post } \\
\text { vaccination(pv) }\end{array}$ & $\begin{array}{c}\text { Post } \\
\text { booster(pb) }\end{array}$ \\
\hline
\end{tabular}

$\begin{array}{cccccc}108 & 2 & 2 & 2 & 32 & -\mathrm{c} \\ 134 & \mathrm{nt}^{\mathrm{b}} & 2 & 2 & 256 & - \\ 101 & 4 & 2 & 2 & 32 & - \\ 111 & 2 & 4 & 4 & 64 & - \\ 121 & 2 & 4 & 2 & 64 & - \\ 149 & 2 & 8 & 4 & 64 & - \\ 117 & 4 & 4 & 4 & 32 & - \\ 096 & 2 & 4 & 2 & 64 & - \\ 144 & 2 & 4 & 2 & 128 & - \\ 100 & 2 & 8 & 2 & 16 & - \\ 115 & 4 & 8 & 2 & 128 & - \\ 122 & 2 & 8 & 2 & 64 & - \\ 137 & 8 & 2 & 2 & 64 & - \\ 130 & 2 & <2 & 4 & 256 & - \\ 139 & <2 & 4 & 4 & 128 & - \\ 133 & <2 & 2 & 4 & 128 & - \\ 116 & <2 & <2 & 2 & 128 & - \\ 118 & <2 & <2 & 4 & 256 & - \\ 131 & 4 & 4 & 16 & 64 & - \\ 148 & 4 & 4 & 2 & 128 & - \\ 141 & <2 & <2 & 2 & 256 & - \\ 138 & <2 & 2 & 4 & 256 & - \\ 120 & <2 & <2 & 2 & 128 & - \\ 147 & <2 & <2 & 2 & 64 & -\end{array}$

a All animals were seronegative at the day of vaccination (VN titers $<2$ );

b Non-tested; ${ }^{c}$ Negative in the anti-gE ELISA.

VN titers reaching from 16 to 256 at day 14 post-revaccination. Even animals harboring low VN titers at day 240 responded effectively to the booster immunization (Table 3).

Selected serum samples collected at different time points after immunization (VN titers of 4, 8, 16 and 32 against the homologous virus) reacted with a range of BoHV-5 and BoHV-1 isolates in VN tests (Fig.2). In general, VN titers against BoHV-5 isolates were identical, one

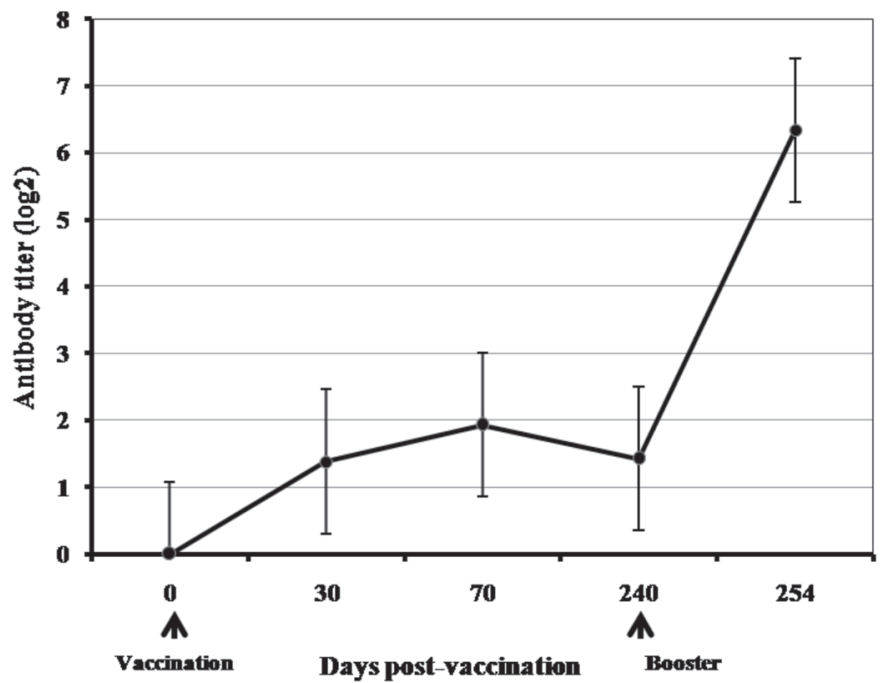

Fig.1. Mean antibody titers to the homologous virus in sera of calves immunized with the recombinant virus and revaccinated 240 days later (Exp.3). To calculate the means, VN titers were transformed in geometric mean titers (GMT). The standard error is indicated by error bars.

dilution above or below that to the homologous virus. When tested against BoHV-1 isolates, the three sera reacted in identical dilution, one or two dilutions below that against the recombinant. A serum sample with VN titer of 4 to the homologous virus showed VN titer of 8 against one of the BoHV-1 isolates (SV 1313/93) and $>2$ against the other BoHV-1 isolates (not shown). These results the broad spectrum of reactivity of the antisera produced in response to immunization with the recombinant BoHV-5gE/TK $\Delta$.

\section{DISCUSSION}

The experiments described herein demonstrate the attenuation and immunogenicity for calves of the recombinant BoHV-5 gE/TK $\Delta$, a candidate vaccine strain. The attenuation was initially demonstrated by IN inoculation of a high virus titer in young, highly susceptible calves. Attenuation was also demonstrated in a group of 8-month-old calves inoculated IM, a route routinely used for administration of $M L V$ vaccines. The immunogenicity of the recombinant was further demonstrated in a third group of calves (vaccinated by the IM route) by the induction of a VN response of adequate magnitude in most animals. In addition, VN antibodies developed by vaccinated animals showed a broad spectrum of reactivity with BoHV-5 and BoHV-1 field isolates. Lastly, vaccinated/inoculated animals of all three experimental groups remained negative for $\mathrm{gE}$ antibodies. Taken together, these results are promising towards the use of the recombinant virus in vaccine formulations.

The need for a safe, effective and antigenically marked vaccine has led to the development of recombinant vaccines to be used in Brazil and other South American countries. A gE-deleted BoHV-1 recombinant strain was constructed out a Brazilian BoHV-1.2 isolate (Franco et al. 2002a). The recombinant was attenuated for cattle and induced protection against 

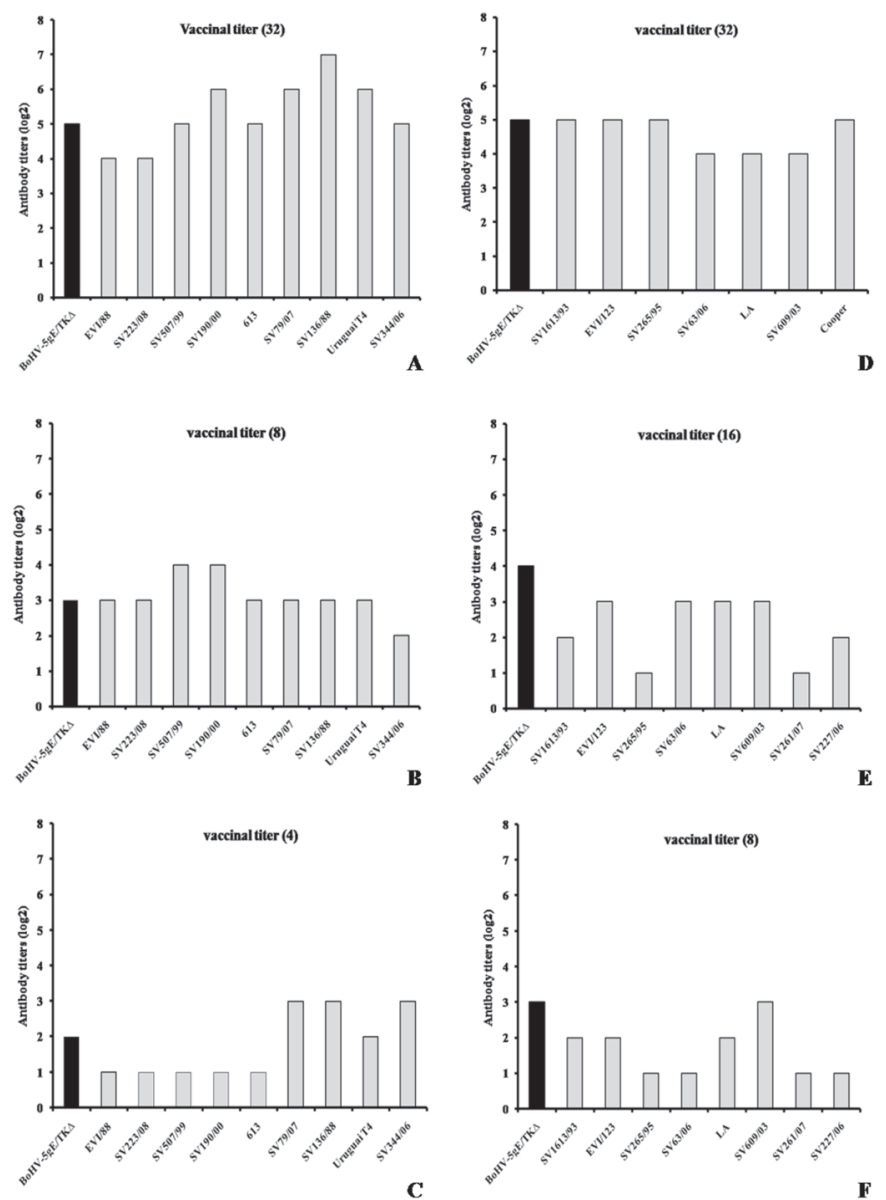

Fig.2. Virus neutralizing (VN) titers to homologous and heterologous viruses in selected sera of calves immunized with the recombinant virus (Exp. 3). Each figure represents the reactivity of serum of one animal. Titers are expressed in $\log _{2}$. Left panel (A-C): VN titers to BoHV-5 isolates; right panel (D-F): VN titers to BoHV-1 isolates. In black are represented the titers to the homologous virus; in gray are shown the titers to the respective isolates.

BoHV-1 by intranasal (Franco et al. 2002b) and genital challenge (Weiss et al. 2010). Recently, a double deletion mutant, defective in the glycoprotein (gE) and thymidine kinase (tk) genes was constructed out of a neurovirulent, well characterized Brazilian BoHV-5 strain (Brum et al. 2010a). Although other herpesvirus glycoproteins have been targeted for deletion (Flores et al. 1993, Van Oirschot et al. 1996, Kaashoek et al. 1998), gE has shown to be a suitable antigenic marker (Van Oirschot et al. 1996, Kaashoek et al. 1996, 1998, Franco et al. 2002a, Van Drunen Little-van den Hurk 2006).

Bovine herpesvirus 1 and PRV gE-negative vaccines have been now used for years in several European countries, the US and Japan (Van Oirschot et al. 1996, van Drunen Littel-van den Hurk et al. 2006). A few studies investigating the effect of $\mathrm{gE}$ deletion on BoHV-5 virulence indicate that the sole $\mathrm{gE}$ deletion may not suffice to produce adequate attenuation, at least in the rabbit model (Chowdhury et al. 2000, Silva et al. 2010). Thus, we introduced an additional deletion in the viral genome, targeting the gene encoding the enzyme thymidine kinase (tk) (Brum et al. 2010a). Bovine herpesvirus tk-deletion mutants have been shown to be attenuated, probably due to a defective replication in neurons (Kit et al. 1985, Whetstone et al. 1992, Van Engelenburg et al. 1994, Kaashoek et al. 1996, Silva et al. 2010).

The attenuation of the recombinant BoHV- $5 \mathrm{gE} / \mathrm{TK} \Delta$ was previously demonstrated in a rabbit model (Silva et al. 2010). Weanling rabbits inoculated IN with the double mutant replicated and shed much less virus, and for a shorter period than rabbits inoculated with the parental virus, and remained healthy during acute infection (Silva et al. 2010). In addition, the recombinant virus was not reactivated from latent infection upon Dx treatment (Silva et al. 2010). In the present study, highly susceptible calves inoculated IN with a high virus titer shed virus in low to moderate titers for a short period; did not present systemic or local signs during acute infection; and did not shed virus upon Dx treatment. A group of five calves (60-90 days old) inoculated with the same amount of SV507/99 shed virus for an average time of 10.8 days (data not show). In other studies, calves were inoculated intranasally with the same isolate (wild type SV 507/99) and virus shedding was detected up to 21 days in some animals (Vogel et al. 2003, 2004).

As an eventual MLV vaccine would be designed for parenteral use, the safety of the recombinant virus was further investigated by IM inoculation of 8-month-old calves (Exp.2). Inoculated animals did not shed virus in secretions and remained healthy during the clinical monitoring. Reactivation of latent infection was not attempted in these animals. Regardless, the failure to recover virus after Dx treatment of IN-inoculated calves strongly suggested that virus reactivation in IM-inoculated animals would be very unlikely. Although latency may be established, reactivation and shedding of BoHV-1 and BoHV-5 strains after IM administration has not been demonstrated (Jones et al. 2000). Furthermore, gE gene-deleted BoHV-1 and BoHV-5 strains are not shed upon Dx treatment (even after IN inoculation), probably reflecting a deficiency in anterograde transneuronal transport (Kaashoek et al. 1998, Mars et al. 2000, Franco et al. 2002b, Liu et al. 2008, Brum et al. 2009). Taken together, these results demonstrate the attenuation and safety of the recombinant BoHV- $5 \mathrm{gE} / \mathrm{TK} \Delta$ for young calves, a highly desired property of a virus strain designed to be used in MLV vaccines.

A previous study demonstrated that the double deletion did not affect adversely the immunogenicity of the recombinant virus upon use in an inactivated, aluminum hydroxide-adjuvanted vaccine formulation (Brum et al. $2010 \mathrm{~b})$. On the other hand, the replication efficiency of the recombinant virus was markedly reduced in the rabbit model (Silva et al. 2010). Since the immunogenicity of a bovine herpesvirus is strongly dependent upon the replication efficiency (Kaashoek et al. 1996, 1998), a deficient replication in the host would compromise its potential use in MLV formulations. Fortunately, our data support that the replication of the recombinant strain was sufficient to induce an adequate VN response in most animals, either after IN 
(Exp.1, Table 1) or IM administration (Exp.2 and 3, Tables 2 and 3, respectively). In a group of calves observed longer (Exp.3), VN titers induced by vaccination remained almost unaltered for up to 8 months. Furthermore, a booster vaccination performed 240 days after the first dose triggered a prompt and strong anamnestic serological response, confirming the adequate immunization/priming by primevaccination. Even though cell-mediated immune response is believed to play a predominant role in protection against herpesvirus infections, VN antibody levels are indicators of the immune response and likely contribute for protection as well (Babiuk et al. 1996).

The high antigenic similarity and cross-neutralization between BoHV-1 and BoHV-5 in vitro (Bratanich et al. 1991, Vogel et al. 2002, Holtz et al. 2009) have suggested that proper immunization with one of these viruses would afford heterologous protection (Del Medico Zajac et al. 2006, Brum et al. 2010b). Nonetheless, immunization of rabbits with a gE-deleted BoHV-1 recombinant conferred insufficient protection upon challenge with a high BoHV-5 titer (Silva et al. 2006). Although cross-protection was not addressed in the present study, serum samples collected from vaccinated animals (Exp.3) showed a broad spectrum of neutralizing activity against several homologous (BoHV-5) and heterologous (BoHV-1) viruses (Fig.2). Furthermore, preliminary data from protection studies demonstrated homologous (BoHV-5) and heterologous (BoHV-1) protection in calves vaccinated with the recombinant BoHV-5gE/TK $\Delta$ (Anziliero et al. manuscript in preparation). Based on these and previous data (Belknap et al. 1994, Del Medico Zajac et al. 2006), we propose that proper immunization of cattle with the recombinant BoHV- $5 \mathrm{gE} / \mathrm{TK} \Delta$ may confer protection to BoHV-5 and BoHV-1 as well.

It is expected that Brazil and other South American countries will follow the North American and European trends of using antigenically marked bovine herpesvirus vaccines in control/eradication programs either at herd or at regional/national levels. In this sense, the results presented herein are promising towards the use of the double mutant in a DIVA vaccine. None of the vaccinated/inoculated animals produced antibodies to $\mathrm{gE}$, even when tested a long time after vaccination, and also after a boost immunization. In contrast, most calves vaccinated IM with an inactivated vaccine containing the parental virus (Brum et al. $2010 \mathrm{~b}$ ) or immunized/inoculated with the live parental virus or with a gE-deleted BoHV-1 seroconverted to gE after 30 or 40 days (Brum et al. 2010b, Weiss et al. 2010, Santos et al. manuscript in preparation). Thus, the serological response induced by the recombinant virus is gE-ELISA differentiable from that induced by infection or immunization with the whole, inactivated or live virus.

In summary, the results presented herein demonstrate that the recombinant BoHV-5gE/TK $\Delta$ is attenuated and immunogenic for calves, induces a serological response differentiable from that derived from infection and, thus, may represent a valuable tool for use in vaccine formulations for the control/prevention of BoHV-1/BoHV-5 infections.

\section{REFERENCES}

Anziliero D., Santos C.M.B., Bauermann F.B., Brum M.C.S., Weiblen R. \& Flores E.F. 2010. Immunization of calves with a recombinant bovine herpesvirus 5 defective in thymidine kinase and glycoprotein E confers protection against BoHV-5 and BoHV-1 challenge. (Manuscript in preparation)

Ackermann M. \& Engels M. 2006. Pro and contra IBR eradication. Vet. Microbiol. 113(3/4):293-302.

Babiuk L.A., Van Drunen Littel-van den Hurk S. \& Tikoo S.K. 1996. Immunology of bovine herpesvirus 1 infection. Vet. Microbiol. 53:3142.

Bratanich A.C., Sardi A.I., Smitsäart E.N. \& Schudel A.A. 1991. Comparative studies of BHV-1 variants by in vivo and in vitro tests. J. Vet. Med. B 38:41-48.

Brum M.C., Coats C., Sangena R.B., Doster A., Jones C. \& Chowdhury S.I. 2009. Bovine herpesvirus type 1 (BoHV-1) anterograde neuronal transport from trigeminal ganglia to nose and eye requires glycoprotein E. J. Neurovirol. 15:196-201.

Brum M.C., Weiblen R., Flores E.F. \& Chowdhury SI. 2010a. Construction and growth properties of bovine herpesvirus type 5 recombinants defective in the glycoprotein $\mathrm{E}$ or thymidine kinase gene or both. Braz. J. Med. Biol. Res. 43:217-224.

Brum M.C.S., Caron L., Chowdhury S.I., Weiblen R. \& Flores E.F. 2010b. Immunogenicity of an inactivated bovine herpesvirus type 5 strain defective in thymidine kinase and glycoprotein E. Pesq. Vet. Bras. 30:57-62.

Belknap E.B., Collins J.K., Ayers V.K. \& Schultheiss P.C. 1994. Experimental infection of neonatal calves with neurovirulent bovine herpesvirus type-5 (BHV-5). Vet. Pathol. 31:358-365.

Caron L., Flores E.F., Weiblen R., Scherer C.F.C., Irigoyen L.F., Roehe P.M., Odeon A. \& Sur J-H. 2002. Latent infection by bovine herpesvirus type- 5 in experimentally infected rabbits: virus reactivation, shedding and recrudescence of neurological disease. Vet. Microbiol. 84(4):285295.

Carrillo B.J., Ambrogí A., Schudel A.A., Vazquez M., Dahme E. \& Pospischil A. 1983. Meningoencephalitis caused by IBR virus in calves in Argentina. Zbl. Vet. Med. B 30:327-332.

Chowdhury S.I., Lee B.J., Ozkul A. \& Weiss M.L. 2000. Bovine herpesvirus 5 glycoprotein $E$ is important for neuroinvasiveness and neurovirulence in the olfactory pathway of the rabbit. J. Virol. 74:20942106.

Colodel E.M., Nakazato L., Weiblen R., Mello R.M., Silva R.R.P., Souza M.A., Filho J.A.O. \& Caron L. 2002. Meningoencefalite necrosante em bovinos causada por herpesvírus bovino no estado de Mato Grosso do Sul, Brasil. Ciência Rural 32:293-298.

Del Médico Z.M.P., Puntel M., Zamorano P.I., Sadir A.M. \& Romera S.A. 2006. BHV-1 vaccine induces cross-protection against BHV-5 disease in cattle. Res. Vet. Sci. 81(3):327-34.

Delhon G., Moraes M.P., Lu Z., Afonso C.L., Flores E.F., Weiblen R., Kutish G.F. \& Rock D.L. 2003. Genome of bovine herpesvirus 5. J. Virol. 77(19):10339-10347.

Engels M. \& Ackermann M. 1996. Pathogenesis of ruminant herpesvirus infections. Vet. Microbiol. 53:3-15.

Flores E.F., Osorio F.A., Zanella E.L., Kit S. \& Kit M. 1993. Efficacy of a deletion mutant bovine herpesvirus-1 (BHV-1) vaccine that allows serologic differentiation of vaccinated from naturally infected animals. J. Vet. Diagn. Invest. 5:534-540.

Flores E.F. \& Donis R. 1995. Isolation of a mutant MDBK cell line resistant to bovine virus diarrhea virus (BVDV) due to a block in viral entry. Virol. 208:565-575.

Franco A.C., Rijsewijk F.A.M., Flores E.F., Weiblen R. \& Roehe P.M. 2002a. Construction and characterization of a glycoprotein $E$ deletion mutant of bovine herpesvirus type 1.2 strain isolated in Brazil. Braz. J. Microbiol. 33(3):274-278. 
Franco A.C., Spilki F.R., Esteves P.A., Lima M., Weiblen R., Flores E.F., Rijsewijk F.A.M., Roehe P.M. 2002b. A Brazilian Glycoprotein E-negative bovine herpesvirus type 1.2a (BHV-1.2a) mutant is attenuated for cattle and induces protection against wild-type virus challenge. Pesq. Vet. Bras. 22(4):135-140.

Holz C.L., Cibulski S.P., Teixeira T.F., Batista H.B.C.R., Campos F.S., Silva R.S., Varela A.P.M., Cenci A., Franco A.C. \& Roehe P.M. 2009. Soroprevalência de herpesvírus bovinos tipos 1 e/ou 5 no Estado do Rio Grande do Sul. Pesq. Vet. Bras. 29:767-773.

Jones C., Newby T.J., Holt T., Doster A., Stone M., Ciacci-Zanella J., Webster C.J. \& Jackwood M.W. 2000. Analysis of latency in cattle after inoculation with a temperature sensitive mutant of bovine herpesvirus 1 (RLB106). Vaccine 18(27):3185-3195.

Kaashoek M.J., Van Engelenburg F.A., Moerman A., Gielkens A.L., Rijsewijk F.A., Van Oirschot J.T. 1996. Virulence and immunogenicity in calves of thymidine kinase and glycoprotein E-negative bovine herpesvirus 1 mutants. Vet. Microbiol. 48(1/2):143-153.

Kaashoek M.J., Rijsewijk F.A., Ruuls R.C., Keil G.M., Thiry E., Pastoret P.P., Van Oirschot J.T. 1998. Virulence, immunogenicity and reactivation of bovine herpesvirus 1 mutants with a deletion in the $\mathrm{gC}, \mathrm{gG}, \mathrm{gl}, \mathrm{gE}$, or in both the $\mathrm{gl}$ and $\mathrm{gE}$ gene. Vaccine 16(8):802-809.

Kahrs R.F. 2001. Infectious bovine rhinotrachitis and infectious pustular vulvovaginitis, p.159-170. In: Kahrs R.F. (Ed.), Viral Disease of Cattle. lowa State University Press, Ames.

Kit S., Qavi H., Gaines J.D., Billingsley P. \& McConnell S. 1985. Thymidine kinase-negative bovine herpesvirus type 1 mutant is stable and highly attenuated in calves. Arch. Virol. 86:63-83.

Liu Z.F., Brum M.C.S., Doster A., Jones C. \& Chowdhury S.I. 2008. A Bovine Herpesvirus Type 1 (BHV-1) Mutant virus specifying a carboxyl terminal truncation of glycoprotein $\mathrm{E}(\mathrm{gE})$ is defective in anterograde neuronal transport in rabbits and calves. J. Virol. 82:74327442.

Mars M.H., de Jong M.C. \& van Oirschot J.T. 2000. A gE-negative bovine herpesvirus 1 vaccine strain is not re-excreted nor transmitted in an experimental cattle population after corticosteroid treatments. Vaccine 18:1975-1981.

Rissi D.R., Rech R.R., Flores E.F., Kommers G.D. \& Barros C.L. 2007. Meningoencephalitis by bovine herpesvirus-5. Pesq. Vet. Bras. 27(7):251-260.

Rock D.L. 1994. Latent infection with bovine herpesvirus type 1. Sem. Virol. 5(3):233-240.

Roizman B. 1992. The family Herpesviridae: An update. Arch.Virol. 123:425-449.

Reed L. \& Muench H.A. 1938. Simple method of estimating fifth percent endpoints. Am. J. Hyg. 27:493-497.

Salvador S.W.C., Lemos R.A.A., Riet-Correa F., Roehe P.M. \& Osorio A.L.A.R. 1998. Meningoencefalite em bovinos causada por herpesvírus bovino-5 no Mato Grosso do Sul e São Paulo. Pesq. Vet. Bras. 18:76-83.

Santos C.M.B., Anziliero D., Bauermann F.B., Brum M.C.S., Weiblen
R. \& Flores E.F. 2010. Experimental infection of calves with bovine herpesvirus 5 recombinants defective in the genes encoding glycoprotein E, thymidine kinase or both. (Manuscript in preparation)

Silva A.D., Spilki F.R., Franco A.C., Esteves P.A., Hübner S.O., Driemeier D., Oliveira A.P., Rijsewijk F.A.M. \& Roehe P.M. 2006. Vaccination with a $\mathrm{gE}$-negative bovine herpesvirus type 1 vaccine confers insufficient protection to a bovine herpesvirus type 5 challenge. Vaccine 24(16):3313-3320.

Silva M.S., Brum M.C.S., Loreto E.L., Weiblen R. \& Flores E.F. 2007. Molecular and antigenic characterization of Brazilian bovine herpesvirus type 1 isolates recovered from the brain of cattle with neurological disease. Virus Res. 129:191-199.

Silva S.C., Brum M.C., Weiblen R., Flores E.F. \& Chowdhury S.I. 2010. A bovine herpesvirus 5 recombinant defective in the thymidine kinase (TK) gene and a double mutant lacking TK and the glycoprotein E gene are fully attenuated for rabbits. Braz. J. Med. Biol. Res. 43:150-159.

Studdert M.J. 1990. Bovine encephalitis herpesvirus. Vet. Rec. 126:2122.

Thrusfield M. 1986. Serological epidemiology, p.175-186. In: Ibid. (Ed.), Veterinary Epidemiology. Butterworths, London. 280p.

Van Drunen Littel-van den Hurk S. 2006. Rationale and perspectives on the success of vaccination against bovine herpesvirus-1. Vet. Microbiol. 113:275-282. Printed in Great Britain 2311

Van Engelenburg F.A.C., Kaashoek M.J., Rijsewijk F.A.M., Van den Burg L., Moerman A., Gielkens A.L.J. \& van Oirschot J.T. 1994. A glycoprotein $\mathrm{E}$ deletion mutant of bovine herpesvirus 1 is avirulent in calves. J. Gen. Virol. 75:2311-2318.

Van Oirschot J.T., Kaashoek M.J., Rijsewijk F.A. \& Stegeman J.A. 1996. The use of marker vaccines in eradication of herpesviruses. J. Biotechnol. 44:75-81.

Vogel F.S.F., Flores E.F., Weiblen R. \& Kunrath C.F. 2002. Atividade neutralizante anti-herpesvírus bovino tipos 1 (BHV-1) e 5 (BHV-5) no soro de bovinos imunizados com vacinas contra o BHV-1. Ciência Rural 32:881-883.

Vogel F.S.F., Caron L., Flores E.F., Weiblen R., Winkelmann E.R., Mayer S.V. \& Bastos R.G. 2003. Distribution of bovine herpesvirus type 5 DNA in the central nervous systems of latently experimentally infected calves. J. Clin. Microbiol. 41(10):4512-4520.

Vogel F.S.F., Lima M., Flores E.F., Weiblen R., Winkemann R., Mayer S.V., Mazzutti K.C., Arenhart S. 2004. Viral replication and shedding during acute infection and after dexamethasone induced reativation of latency in calves inoculated with bovine herpesvirus type 1 (BHV1) and 5 (BHV-5). Ciência Rural 34:1619-1621.

Whetstone C.A., Miller J.M., Seal B.S., Bello L.J. \& Lawrence W.C. 1992. Latency and reactivation of a thymidine kinase-negative bovine herpesvirus 1 deletion mutant. Arch. Virol. 122:207-214.

Weiss M., Vogel F.S.F., Martins M., Weiblen R., Roehe P.M., Franco A. C., Flores E.F. 2010. Genital immunization of heifers with a glycoprotein E-deleted, recombinant bovine herpesvirus 1 strains confers protection upon challenge with a virulent isolate. Pesq. Vet. Bras. 30:4250 . 